\title{
THE QUALITY OF MACRO-ENVIRONMENT AND BUSINESS ENVIRONMENT AND UNIVERSITY STUDENT ENTREPRENEURSHIP - COMPARISON OF THE CZECH AND THE SLOVAK REPUBLIC
}

\author{
Ján DVORSKÝ1, Martin ¿̌EPEL ${ }^{2}$, Gabriela SOPKOVÄ3 , Anna KOTÁSKOV $A^{4}$
}

\begin{abstract}
The aim of this paper was to examine university students' propensity for entrepreneurship in the context of the evaluation of the quality of macro-environment and business environment. A part of this aim was a comparison of defined factors in the Czech and the Slovak Republic. In relation with the research aim, a survey-based research was conducted with university students in the Czech Republic and Slovakia. 409 students in the Czech Republic and 568 students in Slovakia were approached during this research. To verify the defined scientific hypotheses, the regression analysis was used. The research results brought interesting findings, namely that the present macroeconomic environment does not prevent students from starting their own business, and that the present level of basic macroeconomic factors (GDP, employment, inflation) determine the students' propensity for entrepreneurship in both countries. In Slovak Republic, the administrative workload is seen by the students as a factor discouraging them from entrepreneurship after graduating from college. The students feel that the conditions for doing business have improved in the last five years. Students in the Czech Republic think that the conditions for doing business have improved over the past five years, and consider the business environment to be reasonably risky and of good quality.
\end{abstract}

\section{KEY WORDS}

university students, propensity for entrepreneurship

\section{INTRODUCTION}

\footnotetext{
${ }^{1}$ Corresponding address: Ing. Ján Dvorský, Faculty of Management and Economics, Tomas Bata University in Zlín, Mostní 5139, 76001 Zlín, email: jan.dvorsky5@gmail.com

${ }^{2}$ Corresponding address: Dr. Martin Čepel, Ph.D. MBA, Faculty of Economics and Business, Paneuropean University in Bratislava, Tematínska 10, 83000 Bratislava, email: cepel@benzinol.com

${ }^{3}$ Corresponding address: Gabriela Sopková, Mgr. PhD., Faculty of Commerce, University of Economics Bratislava, Dolnozemská cesta 1, 85235 Bratislava, email: gabika.sopkova@gmail.com

${ }^{4}$ Corresponding address: Anna Kotásková, Ing., Faculty of Economics and Business, Paneuropean University in Bratislava, Tematínska 10,83000 Bratislava, email: anna.kotaskova@gmail.com
} 
Entrepreneurship is a significant part of the economic system, having important effects on the growth of the entire society. It is therefore important that the young generation develops an interest in entrepreneurship and starts building actual businesses. Obviously, this is the group of people who should be the most active part of the country's population. It is the very university graduates who should utilize their acquired knowledge and their innate intelligence to form the country's economic power.

Business environment in its broadest sense reflects the quality of the economic environment and the presumption of entrepreneurial subjects' economic activities. A high quality business environment creating conditions for a long-term, sustainable economic growth is the basic precondition for business development and the increase of the country's economic competitiveness on the international scale (Belanová, K., 2014, Ključnikov and Junger, 2013).

This paper examines how the quality of the macroeconomic environment and the business environment determine university students' propensity for entrepreneurship. The originality of this research lies in the quantification of the correlation between university students ${ }^{6}$ propensity for entrepreneurship and the perceived quality of the macroeconomic environment and the business environment.

The structure of the paper is the following: The theoretical part presents the research results of the quality evaluation of the business environment. The second part defines the aim of the research, the methodology, and the description of the data used. The third part presents the results of the research and the discussion about the issue. The conclusion offers a final summary of the research.

\section{THEORETICAL PART}

On the theoretical level, Conorto et al. (2014) define three significant quality areas of the business environment: a broader business environment, a competitive environment, and a narrower business environment. A broader business environment comprises factors on the macroeconomic level that exist regardless of the existence or the rank of individual entrepreneurial subjects. Economic factors are the result of the character and the orientation of the country's economy, while the economic environment influences the changes of the material, energy, financial, investment and information conditions. The economic factors include areas such as inflation tendencies, changes in income and the structure of the consumer spending, the savings and debt rate, evolution of the interest rate, pricing policy, general availability of loans and other means of financing an enterprise, population's money saving and money spending tendency, direct interest rates, etc. The political stability and the political orientation of the country in which the enterprise operates are of a great importance for entrepreneurial subjects. The political factors define the legal conditions and regulate the business environment. The political-legal environment creates a legislative and support frame for entrepreneurial activities, regulates international business relations, the tax and levy politics, the anti-monopoly politics, the stability of the legal environment, the effectivity of the judicial system, the enforceability of the law, the administrative burden on enterprises, etc. Technological factors can, in a narrower sense, be viewed as an industry issue, however, for the business environment in a broader sense, the following factors play an important role: the availability of human capital and the infrastructure in the field of research and development, support of research and development, the state's cooperation with the private sector in this field, etc. The social factors can be considered quite marginal, they only affect the business environment indirectly - values, opinions, and lifestyles of the people in the environment and the evolution of population, cultural, ecological, demographic, religious, and ethnic conditions. The broader economic environment and individual factors are characteristic for their nearly identical evolution and influence on all entrepreneurial subjects on the given market, and their improvement or deterioration has a direct impact on the 
quality of the business environment. The competitive environment comprises barriers to entry, buyer power, supplier power, threat of substitution, and competitive rivalry (the concept of Porter's five forces). The narrower business environment includes direct competitors, customers, suppliers, and employees.

In reality, the following elements may be viewed as the basis of the country's business environment: the legal frame for business and the enforceability of the law; the burden on enterprises (administrative, financial: taxes, levies, and fees); interference with the freedom to do business, and the infrastructure for entrepreneurship (conditions for entrepreneurship, the quality and availability of key production factors and services for entrepreneurs) (Conorto et al., 2014).

Detailed information on the quality of the business environment as a whole and its individual attributes are offered by a number of indexes, such as: the Global Competitiveness Index, the Index of Economic Freedom, the Corruption Perception Index and others that constitute the method of multicriterial evaluation of the country's competitiveness (Belanová, 2014).

It is apparent that the higher the quality of the business environment, the higher the propensity for entrepreneurship, and vice versa. Palalić et al. (2017) state that the higher the dissatisfaction with the current business environment, the higher the demotivation, which negatively affects the students' business intentions.

Many studies confirmed that entrepreneurs with university degrees have significantly better predispositions for doing business. E.g. Lafuente and Vaillant (2013) and Velez (2009) claim that entrepreneurs with university degrees are more interested in the possibility of starting their own business compared to those having a lower level of education. According to Naude et al. (2008), university education is a significant positive factor in entrepreneurship, as educated people are able to see more opportunities on the market that have a positive effect on the company's economic growth (Rauch and Rijsdijk, 2013). This type of education is closely linked to a higher volume of sales, higher profitability, and business sustainability (Van der Sluis and Van Praag, 2008). Millian et al. (2014) state that educated entrepreneurs are able to acquire educated employees on the job market, which has a positive effect on the company's productivity.

Studies conducted within the business environment in the Czech and the Slovak Republic confirmed that entrepreneurs with a university education perceive the intensity of factors that form the business environment differently (Ključnikov et al., 20166 Ključnikov and Sobekova Majková, 2016), and have better predispositions for managing business and financial risks in an enterprise (Belás et al., 2016; Ključnikov and Belás, 2016, Paulik et al., 2015).

The standard and the quality of the macroeconomic environment and the business environment present two important areas that can determine the decision making process regarding entrepreneurship. To understand university students ${ }^{6}$ attitude towards entrepreneurship, it is necessary to know their views and notions, and use this knowledge to create complex conditions that would enable starting and maintaining a business.

\section{RESEARCH AIM, METHODOLOGY AND DATA}

The aim of this paper is to study the university students' propensity for entrepreneurship in the context of the evaluation of the quality of business environment. A part of this aim was a comparison of defined factors in the Czech and the Slovak Republic.

The research was conducted in September 2016 - January of 2017. 409 students from 14 universities in the Czech Republic and 568 students from 8 universities in Slovakia were surveyed. 
The Czech students were from the following universities: Technical University of Liberec, Newton College in Brno - University of Applied Business, University of Economics Prague, Masaryk University in Brno, Sting Academy in Brno, College of Entrepreneurship and Law in Prague, Palacký University Olomouc, and the Mendel University Brno. Students from Slovakia were studying at the following universities: University of Economics in Bratislava, Alexander Dubček University in Trenčín, University of Žilina, University of Prešov, Matej Bel University in Banská Bystrica, Technical University of Zvolen, Technical University of Košice, and Pan-European University in Bratislava. Universities were approached on the basis of willingness to participate in the research. The research focused on students of the 3rd year of Bachelor study and higher grades (Master's degree, engineering studies) who are supposed to be thinking about their future. A total of 409 college students (156 men $(38.2 \%)$ and 253 women $(61.8 \%)$ participated in the survey. There were 568 students from the Slovak universities $(216$ men $(38.0 \%)$ and 352 women $(62.0 \%))$. The data were collected by means of a questionnaire. The questionnaire contained a total of 40 business queries that students had to rate by agreeing to the classical five-level Likert scale: 1 - I strongly disagree, 2 - I do not agree, 3 - I do not agree or disagree; 4 - I agree, 5 - I definitely agree.

In developing this paper, two scientific hypotheses were established:

H1: The macroeconomic environment significantly determines the Czech and Slovak university students' propensity for entrepreneurship.

$\mathrm{H} 2$ : The quality of business environment significantly determines the Czech and Slovak university students' propensity for entrepreneurship.

In this research, the Macroeconomic environment construct was defined, using the following statements:

K31: I consider the macroeconomic environment of my country to be positive for doing business.

K32: The state of macroeconomic environment of my country supports starting a business.

K33: Present macroeconomic environment does not prevent me from starting a business.

K34: Present level of basic macroeconomic factors (GDP, employment, inflation) supports business and creates interesting business opportunities.

In this research, the Quality of the business environment construct was defined, using the following statements:

K41: The business environment of my country is of good quality and convenient for starting a business.

K42: The business environment of my country is relatively risk-resistant and enables me to start a business.

K43: Conditions for doing business have improved in my country in the last five years.

K44: The amount of administrative work of businesspeople in my country has decreased in the last five years.

The dependent variable was defined using the following statement:

KY: I am very interested in doing business.

To evaluate the established scientific hypotheses, the method of mathematical statistics called regression analysis will be used. A graphical analysis of variables was used to confirm the assumption of linearity. The presence of non-linear patterns between the dependent variable (KY) and independent variables (K31, K32,.., K43, and K44) was verified using the Scatter plot. Verification of the assumption of normal independent variables distribution was performed using: 1 . Graphical presentation comparing the probability model of the normal distribution and obtained data for each independent variable; 2 . Testing of the descriptive characteristics (skewness, kurtosis) of independent variables, using the $\mathrm{z}$ - test. The assumption of normal distribution of an independent variable is not confirmed if the value of $z$ - test is larger than 2 (Hair et al., 2010; Luskova et al., 2015). The assumption of homoscedasticity of independent variables was tested using the Bartlett's test (Martínez-López et al., 2013). If $\mathrm{p}$ - value of the Bartlett's test is higher than 0.05 , the assumption is confirmed. The intensity of correlation between the dependent variable 
and independent variable was tested using the correlation coefficient. The correlation results between variables are compiled into a correlation matrix. The critical acceptance value for independent variables into the linear regression model in Slovakia is established at $|\mathrm{t}| \geq 1.952$ (564 degrees of freedom, significance level at 0.05) and for regression models in the Czech Republic at $|\mathrm{t}| \geq 1.941$ (405 degrees of freedom, significance level at 0.05 ). The general multiple regression models for individual countries (Czech Republic, Slovak Republic) were based on the relationship between the dependent variable (KY) and independent variables, as per the scientific hypotheses, as follows:

$$
K Y=\beta_{0}+\beta_{K 31} \times K 31+\beta_{K 32} \times K 32+\beta_{K 33} \times K 33+\beta_{34} \times K 34 \text {, }
$$

where: KY - dependent variable; $\beta_{0}-$ constant; $\beta_{K 31 ;} \beta_{K 32 ;} \beta_{K 33 ;} \beta_{K 34}-$ coefficients of independent variables $(\mathrm{K} 31, \mathrm{~K} 32$, $\mathrm{K} 33$, and $\mathrm{K} 34) ; \mathrm{K} 31, \mathrm{~K} 32, \mathrm{~K} 33$, and $\mathrm{K} 34$ - independent variables.

$$
K Y=\beta_{0}+\beta_{K 41} \times K 41+\beta_{K 42} \times K 42+\beta_{K 43} \times K 43+\beta_{44} \times K 44,
$$

where: KY - dependent variable; $\beta_{0}$ - constant, $\beta_{K 41 ;} \beta_{K 42 ;} \beta_{K 43 ;} \beta_{K 44}-$ coefficients of independent variables (K41, K42, $\mathrm{K} 43$, and K44); K41, K42, K43, and K44 - independent variables.

Multicollinearity can have a negative impact on the calculated coefficients of independent variables in the regression models. The presence of multicollinearity in the regression model is confirmed if the value of the Variance Inflation Factor (VIF) is greater than 5 (Wit et al., 2012; Betakova et al., 2014). The statistical reliability of the proposed regression model is verified using the parametric Ftest of Analysis of variance. If the $p$ - value is lower than the significance level, then the regression model is considered statistically significant. The multiple correlation coefficient characterizes the correlation between variables in the regression model. Size explanation of the variability of the dependent variable using selected independent variables is characterized by the coefficient of determination $\left(\mathrm{R}^{2}\right)$ and adjusted coefficient of determination (Adjusted $\mathrm{R}^{2}$ ). The positive coefficients of independent variables in the regression model indicate a positive impact on the dependent variable. The regression analysis, as well as testing was performed using the IBM SPSS Statistika software for statistical data analysis.

\section{RESULTS AND SHORT DISCUSSION}

The basic structure of students' responses to the question whether they have a strong interest in entrepreneurship (KY) after graduating from college (by country): Czech Republic: I definitely agree - $64(15.6 \%)$, I agree - $138(33.7 \%)$, I do not agree or disagree - $82(20.1 \%)$, I do not agree - $104(25.5 \%)$, and I strongly disagree -21 (5.2\%) of university students in the Czech Republic. Slovak Republic: I definitely agree - 89 (15.6\%), I agree - 245 (43.1\%), I do not agree or disagree $-119(21.0 \%)$, I do not agree - 93 (16.4\%), I strongly disagree - 22 (3.9\%) of university students in the Slovak Republic.

A graphical data analysis performed using the SPSS program between the dependent variable KY and independent variables (K31, K32, K33, and K34) demonstrated linear correlations in both the Czech and the Slovak Republic. The comparison of the normal distribution curve with the independent variable data points at deviations in independent variables K31 and K32 in the Czech Republic and the independent variable K32 in Slovakia. The above mentioned doubts about the verification of normal data distribution assumption, as well as the results of the homoscedasticity assumption testing are shown in Table 1.

Table 1 Skewness, kurtosis, $\mathbf{z}$ - value and Bartlett's test of independent variables

\begin{tabular}{|c|c|c|c|c|c|c|c|c|}
\hline Independent & \multicolumn{4}{|c|}{ CZECH REPUBLIC } & \multicolumn{4}{c|}{ SLOVAK REPUBLIC } \\
\cline { 2 - 9 } Variable & Skewness & Kurtosis & Z- & Bartlett's & Skewness & Kurtosis & Z- & Bartlett's \\
\hline
\end{tabular}




\begin{tabular}{|c|c|c|c|c|c|c|c|c|}
\hline & (S) & $(\mathrm{K})$ & $\begin{array}{c}\text { value } \\
(\mathrm{S}) \\
(\mathrm{K})\end{array}$ & test & (S) & $(\mathrm{K})$ & $\begin{array}{c}\text { value } \\
(\mathrm{S}) \\
(\mathrm{K})\end{array}$ & test \\
\hline \multirow{2}{*}{ K31 } & \multirow{2}{*}{-0.347} & \multirow{2}{*}{-0.122} & 2.026 & \multirow{2}{*}{0.015} & \multirow{2}{*}{0.629} & \multirow{2}{*}{-0.502} & 1.508 & \multirow{2}{*}{0.354} \\
\hline & & & 1.845 & & & & 0.741 & \\
\hline \multirow{2}{*}{ K32 } & \multirow{2}{*}{-0.294} & \multirow{2}{*}{-1.123} & 2.478 & \multirow{2}{*}{0.032} & \multirow{2}{*}{0.463} & \multirow{2}{*}{-0.825} & 2.026 & \multirow{2}{*}{0.019} \\
\hline & & & 3.366 & & & & 3.477 & \\
\hline \multirow{2}{*}{ K33 } & \multirow{2}{*}{-0.780} & \multirow{2}{*}{-0.146} & 1.742 & \multirow{2}{*}{0.184} & \multirow{2}{*}{-0.164} & \multirow{2}{*}{-1.127} & 2.005 & \multirow{2}{*}{0.806} \\
\hline & & & 1.684 & & & & 1.179 & \\
\hline \multirow{2}{*}{ K34 } & \multirow{2}{*}{-0.529} & \multirow{2}{*}{-0.281} & 1.054 & \multirow{2}{*}{0.215} & \multirow{2}{*}{0.141} & \multirow{2}{*}{-0.951} & 2.001 & \multirow{2}{*}{0.231} \\
\hline & & & 0.422 & & & & 1.442 & \\
\hline
\end{tabular}

(Source: Author)

The test results of the normal distribution assumption in the Czech Republic were not confirmed in K31 and K32. However, the independent variable K31 and the results of z - value of skewness only slightly exceed the value of 2. Given the large student research sample (more than 100), the assumption can be considered confirmed, according to Hair et al. (2010). The assumption of normal data distribution in the Slovak Republic is not verified in the independent variable K32. The Bartlett's test results deny the assumption of homoscedasticity in independent variables K31 and K32 in the Czech Republic and K32 in Slovakia.

Table 2 Correlation matrix of dependent variable and independent variables

\begin{tabular}{|c|c|c|c|c|c|c|c|c|c|c|c|}
\hline \multirow{2}{*}{$\mathrm{V}^{*}$} & \multicolumn{5}{|c|}{ CZECH REPUBLIC } & \multirow{2}{*}{$\mathrm{V}^{*}$} & \multicolumn{5}{|c|}{ SLOVAK REPUBLIC } \\
\hline & KY & K31 & K32 & K33 & K34 & & KY & K31 & K32 & K33 & K34 \\
\hline KY & 1 & & & & & KY & 1 & & & & \\
\hline K31 & 0.255 & 1 & & & & K31 & 0.428 & 1 & & & \\
\hline K32 & 0.125 & 0.633 & 1 & & & K32 & 0.181 & 0.613 & 1 & & \\
\hline K33 & 0.958 & 0.323 & 0.403 & 1 & & K33 & 0.831 & 0.338 & 0.371 & 1 & \\
\hline K34 & 0.619 & 0.393 & 0.466 & 0.774 & 1 & K34 & 0.598 & 0.365 & 0.457 & 0.761 & 1 \\
\hline
\end{tabular}

Note: ${ }^{*} \mathrm{~V}$ - dependent variable KY and independent variables (K31, K32, K33, and K34). (Source: Author)

The correlation matrix results indicate that there are weak correlations between the dependent variable KY and independent variables $\mathrm{K} 31$ and $\mathrm{K} 32$ in both countries. On the contrary, the strong correlation (independent variable K33) and very strong correlation (independent variable6 K34) with the dependent variable KY in both countries indicate that these factors will be a part of the regression models.

A partial conclusion is that independent variables $\mathrm{K} 31$ and $\mathrm{K} 32$ are not statistically significant variables in the regression models (Czech Republic and Slovak Republic), as the assumption of a normal data distribution, homoscedasticity, low correlation of KY and $t$ - test results (Czech Republic: $\mathrm{p}$ - value of $\mathrm{t}$ - test for $\mathrm{K} 31=0.354 ; \mathrm{p}$ - value of $\mathrm{t}$ - test for $\mathrm{K} 32=1.007$; Slovak Republic: $\mathrm{p}$ - value of $\mathrm{t}$ - test for $\mathrm{K} 31=0.688$; $\mathrm{p}$ - value of $\mathrm{t}-$ test for $\mathrm{K} 32=0.899$ ) was not confirmed.

The results of the regression equation, the significance of the regression model and the regression model characteristics with statistically significant factors are shown in Table 3.

Table 3 Characteristics of regression models

\begin{tabular}{|c|c|}
\hline CZECH REPUBLIC & SLOVAK REPUBLIC \\
\hline \multicolumn{2}{|c|}{ Least squares multiple regression } \\
\hline
\end{tabular}




\begin{tabular}{|c|c|c|c|c|c|c|c|c|c|}
\hline \multicolumn{4}{|l|}{$\mathrm{R}^{2}$} & 0.469 & & & & & 0.357 \\
\hline \multicolumn{4}{|c|}{ Adjusted $\mathrm{R}^{2}$} & 0.461 & & & & & 0.348 \\
\hline \multicolumn{4}{|c|}{ Multiple correlation coefficient } & 0.685 & & & & & 0.598 \\
\hline \multicolumn{4}{|c|}{ Residual standard deviation } & 0.108 & & & & & 0.094 \\
\hline \multicolumn{10}{|c|}{ Regression equation } \\
\hline $\begin{array}{l}\text { Independe } \\
\text { nt } \\
\text { variables }\end{array}$ & $\begin{array}{l}\text { Coefficie } \\
\text { nt }\end{array}$ & $\begin{array}{l}\text { Std. } \\
\text { Error }\end{array}$ & $\begin{array}{l}\mathrm{t}- \\
\text { Test }\end{array}$ & $\begin{array}{l}\mathrm{p}- \\
\text { value }\end{array}$ & \begin{tabular}{|l} 
Independe \\
nt \\
variables \\
\end{tabular} & $\begin{array}{l}\text { Coefficie } \\
\text { nt }\end{array}$ & $\begin{array}{l}\text { Std. } \\
\text { Error }\end{array}$ & $\begin{array}{l}\mathrm{t}- \\
\text { Test }\end{array}$ & $\begin{array}{l}\mathrm{p}- \\
\text { value }\end{array}$ \\
\hline Constant & & & & & Constant & & & & \\
\hline K33 & 0.214 & 0.087 & 2.459 & 0.014 & K33 & 0.385 & 0.091 & 4.231 & 0.003 \\
\hline K34 & 0.428 & 0.177 & 2.418 & 0.015 & K34 & 0.279 & 0.125 & 2.232 & 0.021 \\
\hline \multicolumn{10}{|c|}{ Analysis of variance } \\
\hline \multicolumn{4}{|l|}{ F-test } & 13.058 & & & & & 9.288 \\
\hline \multicolumn{4}{|l|}{ P-value } & 0.024 & & & & & 0.044 \\
\hline
\end{tabular}

(Source: Author)

The $\mathrm{t}$ - test results confirmed the statistical significance of independent variables K33 and K34 in both countries. The created regression models are statistically significant (Czech Republic: p- value of F- test $=0.024$; Slovak Republic: $\mathrm{p}$ - value of F- test $=0.044$ ). Multicollinearity is not present in the regression models. Up to $46.9 \%$ of the variability of students ${ }^{6}$ significant interest in entrepreneurship after college graduation in the Czech Republic can be explained by the fact that the country's macroeconomic environment does not prevent students from starting a business and that the present values of macroeconomic factors support business by creating interesting business opportunities. In the Slovak Republic, $35.7 \%$ of the variability of students' significant interest in entrepreneurship after college graduation can be explained by the above mentioned factors. The regression models with a linear function for respective countries are formed as follows:

$$
\text { Czech Republic: } \quad K Y=0.214 \times K 33+0.428 \times K 34
$$

(3)

\section{Slovak Republic: $\quad K Y=0.384 \times K 33+0.279 \times K 34$}

(4)

Students in the Slovak Republic state that the macroeconomic environment does not prevent them from starting a business, which is a more positive view than that of the Czech students. On the contrary, students in the Czech Republic rate the present level of business support and the creation of interesting business opportunities more positively than students in Slovakia. The above mentioned results indicate that the macroeconomic environment determines the students ${ }^{6}$ propensity for entrepreneurship in both countries.

\section{Hypothesis $H 1$ is confirmed.}

The graphical analysis of data performed in the SPSS program between the dependent variable KY and independent variables (K41, K42, K43, and K44) demonstrates linear correlations in both the Czech and the Slovak Republic. The comparison of the normal distribution curve with the independent variable data does not point at deviations in independent variables in the Czech Republic, but points at deviations in the independent variable K43 in Slovakia. The results of assumption verification of normal data distribution, as well as the results of the homoscedasticity assumption testing are shown in Table 4.

Table 4 Skewness, kurtosis, z- value and Bartlett's test of independent variables

\begin{tabular}{|c|c|c|c|c|c|c|c|c|}
\hline \multirow{2}{*}{$\begin{array}{c}\text { Independent } \\
\text { Variable }\end{array}$} & \multicolumn{4}{|c|}{ CZECH REPUBLIC } & \multicolumn{3}{c|}{ SLOVAK REPUBLIC } \\
\cline { 2 - 9 } & $\begin{array}{c}\text { Skewness } \\
(\mathrm{S})\end{array}$ & $\begin{array}{c}\text { Kurtosis } \\
(\mathrm{K})\end{array}$ & $\begin{array}{c}\text { Z-value } \\
(\mathrm{S}),(\mathrm{K})\end{array}$ & $\begin{array}{c}\text { Bartlett's } \\
\text { test }\end{array}$ & $\begin{array}{c}\text { Skewness } \\
(\mathrm{S})\end{array}$ & $\begin{array}{c}\text { Kurtosis } \\
(\mathrm{K})\end{array}$ & $\begin{array}{c}\text { Z-value } \\
(\mathrm{S}),(\mathrm{K})\end{array}$ & $\begin{array}{c}\text { Bartlett's } \\
\text { test }\end{array}$ \\
\hline K41 & -0.152 & -1.157 & 0.851 & 0.285 & 0.813 & -0.290 & 2.584 & 0.041 \\
\hline
\end{tabular}




\begin{tabular}{|c|c|c|c|c|c|c|c|c|}
\hline & & & 0.656 & & & & 0.245 & \\
\hline \multirow{2}{*}{ K42 } & \multirow{2}{*}{-1.066} & \multirow{2}{*}{0.036} & 1.783 & \multirow{2}{*}{0.885} & \multirow{2}{*}{-0.335} & \multirow{2}{*}{-1.207} & 1.164 & \multirow{2}{*}{0.431} \\
\hline & & & 1.654 & & & & 1.312 & \\
\hline \multirow{2}{*}{ K43 } & \multirow{2}{*}{-0.242} & \multirow{2}{*}{-0.466} & 1.934 & \multirow{2}{*}{0.339} & \multirow{2}{*}{-0.024} & \multirow{2}{*}{-0.024} & 2.011 & \multirow{2}{*}{0.109} \\
\hline & & & 0.847 & & & & 2.057 & \\
\hline \multirow{2}{*}{ K44 } & \multirow{2}{*}{0.360} & \multirow{2}{*}{-0.433} & 0.355 & \multirow{2}{*}{0.088} & \multirow{2}{*}{0.207} & \multirow{2}{*}{0.207} & 1.558 & \multirow{2}{*}{0.115} \\
\hline & & & 1.522 & & & & 1.363 & \\
\hline
\end{tabular}

(Source: Author)

The test results of the normal distribution assumption and homoscedasticity in the Czech Republic were confirmed in all independent variables. In the Slovak Republic, the $\mathrm{z}$ - value of skewness and kurtosis of independent variable K43 is above 2. Given the large student research sample (568 students), the assumption can be considered confirmed. However, the assumption of normal distribution in the independent variable K41 is rejected. The results of the Bartlett's test confirm the assumption of homoscedasticity in all independent variables except K41 (Bartlett's test $=0.041)$ in the Slovak Republic.

Table 5 Correlation matrix of dependent variable and independent variables

\begin{tabular}{|c|c|c|c|c|c|c|c|c|c|c|c|}
\hline \multirow{2}{*}{$\mathrm{V}^{*}$} & \multicolumn{5}{|c|}{ CZECH REPUBLIC } & \multirow{2}{*}{$\mathrm{V}^{*}$} & \multicolumn{5}{|c|}{ SLOVAK REPUBLIC } \\
\hline & KY & K41 & K42 & $\mathrm{K} 43$ & K44 & & KY & K41 & $\mathrm{K} 42$ & $\mathrm{~K} 43$ & K44 \\
\hline KY & 1 & & & & & KY & 1 & & & & \\
\hline K41 & 0.781 & 1 & & & & K41 & 0.270 & 1 & & & \\
\hline $\mathrm{K} 42$ & 0.585 & 0.563 & 1 & & & K42 & 0.821 & 0.399 & 1 & & \\
\hline K43 & 0.611 & 0.674 & 0.809 & 1 & & K43 & 0.573 & 0.396 & 0.652 & 1 & \\
\hline $\mathrm{K} 44$ & 0.707 & 0.755 & 0.722 & 0.629 & 1 & K44 & 0.875 & 0.260 & 0.684 & 0.844 & 1 \\
\hline
\end{tabular}

Notes: ${ }^{*} \mathrm{~V}$ - dependent variable KY and independent variables (K41, K42, K43, and K44).

(Source: Author)

The results of the correlation matrix indicate that in the Czech Republic, there are strong correlations between the dependent variable KY and independent variables (K41, K42, K43, and $\mathrm{K} 44$ ). In the Slovak Republic, there is a very low correlation between the dependent variable KY and the independent variable $\mathrm{K} 41$, and a partial correlation between $\mathrm{KY}$ and $\mathrm{K} 43$. There is a very strong correlation between KY and independent variables K42 and K44 (R > 0.800).

A partial conclusion is that the independent variable K41 is not a statistically significant variable in the regression model in the Slovak Republic, as the assumption of a normal data distribution, homoscedasticity, low correlation with KY and t-test results (Slovak Republic: $\mathrm{p}$ - value of $\mathrm{t}$ - test for $\mathrm{K} 41=0.354$ ) was not confirmed.

The results of statistically significant independent variables, statistical significance of proposed regression models, and regression model characteristics are shown in Table 6.

Table 6 Characteristics of regression model in Czech Republic and Slovak Republic

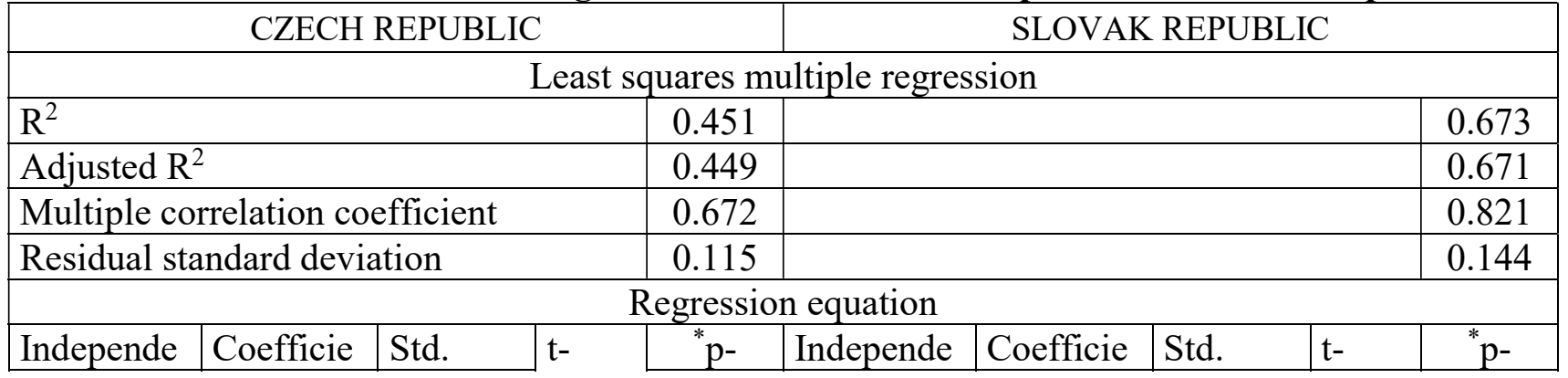


International Journal of Entrepreneurial Knowledge Issue 2/2017, Volume 5

\begin{tabular}{|c|c|c|c|c|c|c|c|c|c|}
\hline $\begin{array}{l}\text { nt } \\
\text { variables }\end{array}$ & nt & Error & Test & $\begin{array}{l}\text { value } \\
{ }^{* *} \text { VIF }\end{array}$ & $\begin{array}{l}\text { nt } \\
\text { variables }\end{array}$ & nt & Error & Test & $\begin{array}{l}\text { value } \\
{ }^{* *} \text { VIF }\end{array}$ \\
\hline Constant & & & & & Constant & & & & \\
\hline K41 & 0.193 & 0.064 & 3.016 & \begin{tabular}{|l|}
$0.011^{*}$ \\
$2.156^{* *}$
\end{tabular} & K42 & 0.155 & 0.067 & 2.313 & $\begin{array}{l}0.016^{*} \\
1.574^{* *}\end{array}$ \\
\hline K42 & 0.201 & 0.110 & 1.827 & \begin{tabular}{|c|}
$0.047^{*}$ \\
$1.835^{* *}$ \\
\end{tabular} & K43 & 0.309 & 0.132 & 2.341 & $\begin{array}{l}0.015^{*} \\
1.644^{* *}\end{array}$ \\
\hline K43 & 0.645 & 0.227 & 2.841 & \begin{tabular}{|c|}
$0.019^{*}$ \\
$3.148^{* *}$
\end{tabular} & K44 & -0.376 & 0.206 & $\begin{array}{c}- \\
1.825\end{array}$ & $\begin{array}{l}0.048^{*} \\
2.199^{* * *}\end{array}$ \\
\hline K44 & 0.358 & 0.138 & 2.594 & \begin{tabular}{|c|}
$0.024^{*}$ \\
$2.833^{* *}$
\end{tabular} & & & & & \\
\hline \multicolumn{10}{|c|}{ Analysis of variance } \\
\hline F-test & & & & 12.351 & & & & & 10.222 \\
\hline P-value & & & & 0.031 & & & & & 0.038 \\
\hline
\end{tabular}

Note: ${ }^{*} \mathrm{p}$ - value of $\mathrm{t}$ - test; ${ }^{* *} \mathrm{VIF}$ - Variance inflation factor (Source: Author)

Results of $\mathrm{t}$ - tests confirmed the statistical significance of independent variables K41, K42, K43 in the Czech Republic, as well as K42, K43, K44 in the Slovak Republic ( $\mathrm{p}$ - value of $\mathrm{t}$ - test <0.05). The created regression models are statistically significant (Czech Republic: $\mathrm{p}-$ value of $\mathrm{F}$ - test $=$ 0.031; Slovak Republic: $\mathrm{p}$ - value F- test $=0.038$ ). Multicollinearity is not present in the regression models, as the results of VIF $>5$. Regression models with a linear function for respective countries are as follows:

Czech Republic: $\quad K Y=0.193 \times K 41+0.201 \times K 42+0.645 \times K 43+0.358 \times K 44$

(5)

Slovak Republic: $\quad K Y=0.155 \times K 42+0.309 \times K 43-0.376 \mathrm{~K} 44$

(6)

Up to $45.1 \%$ of the variability of students ' significant interest in entrepreneurship after college graduation in the Czech Republic can be explained by the quality of the business environment, reasonable risk rate in the business environment, improvement of conditions for doing business in the past 5 years, as well as reduction of administrative burden on enterprises in the past 5 years. In Slovakia, approximately $67 \%$ of the variability of students' significant interest in entrepreneurship after college graduation can be explained by the reasonability of the business environment's risk rate and the improvement of conditions for doing business in the past 5 years. However, the administrative burden on enterprises has a negative effect on entrepreneurship and lowers students ${ }^{6}$ propensity for entrepreneurship. The Quality of business environment construct defined in this paper determines the propensity for entrepreneurship of those students who have a strong interest in starting a business after graduating from college, regardless of their country of origin.

\section{Hypothesis $H 2$ is confirmed.}

Among the main features of the Czech business environment are primarily economic and financial factors such as macroeconomic indicators, but also legislative and political factors or the social climate. Business environment is where the interests of more than one group meet, be it the interest of individual entrepreneurs, cities, townships, counties, or the state. It is a society-wide interest of every country to put emphasis on increasing the quality of the business environment.

Results obtained in this research detailing students ${ }^{6}$ evaluation of the business environment and the macroeconomic environment in the Czech Republic correspond with the results of statistical findings of the Czech National Bank which claims that in the Czech Republic, there has been a long-term improvement of the quality of the business environment primarily due to the improvement of seven out of ten indicators compared within the time period of 5 years. The biggest improvement can be seen in the area of corruption and the bureaucracy of administrative burden on enterprises (Kyněra, 2016). 
The results of the research among the V4 countries' students conducted by Okreglicka et al. (2017) on a sample of 300 students in 2016 indicate that even though Polish students have a higher propensity for entrepreneurship, the university's role in creating entrepreneurial intentions or reviewing them is smaller than in the Czech or the Slovak Republic. These results offer an interesting finding: universities specializing in economics in both the Slovak and the Czech Republic put a great emphasis on university graduates' employability.

It is interesting to see that in the time period between 2015 and 2016, there has been an increase in the average number of viewings of resumes posted by students from University of Economics in Bratislava and Slovak Technical University in Bratislava, according to the largest online job portal in Slovakia (www.profesia.sk). These students' resumes are on the top two ranks of the scale. Students' employability, along with improved macroeconomic indicators in the form of the lowest unemployment rate in the Slovak Republic increases their attractiveness on the job market.

\section{CONCLUSION}

The aim of this paper is to study the university students ' propensity for entrepreneurship in the context of the evaluation of the quality of business environment. A part of this aim was a comparison of defined factors in the Czech and the Slovak Republic.

The results of this research have brought interesting findings, namely that the present macroeconomic environment does not prevent students from starting their own business, and that the present level of basic macroeconomic factors such as the GDP, employment, and inflation determine the students' propensity for entrepreneurship in both countries. In Slovak Republic, the administrative workload is seen by the students as a factor discouraging them from entrepreneurship after graduating from college. The students feel that the conditions for doing business have improved in the last five years. Students in the Czech Republic think that the conditions for doing business have improved over the past five years, and consider the business environment to be reasonably risky and of good quality.

The results of university graduates ' propensity for entrepreneurship achieved using the regression analysis are limited by the size of the student sample. A verification of the achieved results is definitely needed with a larger sample of students in both countries. Despite this limitation, the diversity of the approached students from 14 universities in the Czech Republic and 8 universities in the Slovak Republic makes the results interesting not only for the academic society, but mainly for the supporting subjects dealing with the business environment of both countries.

The next research will focus on students' social environment and the state's support of entrepreneurship. It is assumed that social environment factors such as family status, society, politicians, and media have an influence on the university graduates ${ }^{6}$ propensity for entrepreneurship. However, the state's support of entrepreneurship and the forms of support of the business environment in the country can significantly influence a young person contemplating starting a business, and determine his or her propensity for entrepreneurship.

\section{LITERATURE}

Belás, J., Vojtovič, S., Ključnikov, A. (2016). Microenterprises and Significant Risk Factors in Loan Process. Economics and Sociology, Vol. 9, No 1, pp. 43-59. 
Belanová, K. (2014). Komparácia kvality podnikatel'ského prostredia v krajinách Vyšehradskej štvorky s osobitným akcentom na dostupnost' finančných zdrojov. Biatec. Vol. 22(1), pp. 1217.

Betáková, J., Lorko, M., Dvorský, J. (2014). The impact of the potential risks of the implementation of instruments for environmental area management on the development of urban settlement. WIT Transactions on Ecology and the Environment, Vol. 181, pp. 91-102.

Conorto, R. et al. (2014). Analýza, monitor kvality podnikatel'ského prostredia v SR a konkurencie schopnost' ekonomiky. Bratislava: Centrum vzdelávania MPSVR SR.

Hair, J. F., Black, W. C., Babin, B. J., Anderson, R. E. (2010). Multivariate data analysis. New Jersey: Upper Saddle River: Prentice Hall. ISBN-13: 978-0138132631.

Ključnikov, A., Belás, J., Kozubíková, L., Paseková, P. (2016). The Entrepreneurial Perception of SME Business Environment Quality in the Czech Republic. Journal of Competitiveness, Vo. 8, Issue 1, pp. 66-78.

Ključnikov, A. and Belás, J. (2016). Approaches of Czech Entrepreneurs to Debt Financing and Management of Credit Risk. Equilibrium. Quarterly Journal of Economics and Economic Policy, 11(2), 343-365.

Ključnikov, A., Junger, R. (2013). Barriers for foreign direct investments in Belarus: Case of business logistics. In Proceedings of the Carpathian Logistics Congress.

Ključnikov, A., Sobeková Majková, M. (2016). Impact of Gender in the Perception of Administrative Burdens among Young Entrepreneurs - Evidence from Slovakia. Journal of Competitiveness, 8(2), pp. 17 - 30.

Kyněra, J. (2016). Dostupné online: https://roklen24.cz/a/iuG4h/kvalita-podnikatelskeho-prostrediv-cr-se-dal-zlepsuje.

Lafuente, E. M. and Vaillant, Y. (2013). Age Driven Influence of Role-Models on Entrepreneurship in a Transition Economy. Journal of Small Business and Enterprise Development, Vol. 20(1), pp. 181-203.

Lusková, M., and Hudáková, M. (2015). Making the process of university teachers' motivation more effective. Turkish Online Journal of Educational Technology, 2015, 308-313.

Martínez-López, F. J., Gázquiz-Abad, J. C., Sousa, C. M. P. 2013. Structural equation modelling in marketing and business research: Critical issues and practical recommendations", European Journal of Marketing, Vol. 47 (1/2), pp. 115-152.

Millian, J. M., Congregado, E., Roman, C., Van Praag, M., and Van Stel, A. (2014). The Value of an Educated Population for an Individual's Entrepreneurship Success. Journal of Business Venturing, Vol. 29, pp. 312-632.

Naude, W., Gries, T., Wood, E., and Meintjiess, A. (2008). Regional determinants of Entrepreneurial Startups in a Developing Country. Entrepreneurship and Regional Development, Vol. 20, pp. 111-124. 
Okręglicka, M., Havierniková, K., Mynarzová, M., \& Lemańska-Majdzik, A. (2017). Entrepreneurial intention creation of students in Poland, Slovakia and Czechia. Polish Journal of Management Studies, Vol.15 (2), pp.162-172.

Palalić, R., Ramadani, V., Đilović, A., Dizdarević, A., Ratten, V. (2017), „Entrepreneurial intentions of university students: a case-based study", Journal of Enterprising Communities: People and Places in the Global Economy. https://doi.org/10.1108/JEC-12-2016-0046

Paulík, J., Kombo, F., Ključnikov, A. (2015). CSR as a driver of satisfaction and loyalty in commercial banks in the Czech Republic. Journal of International Studies, 8(3), pp. 111-126.

Rauch, A. and Rijsdijk, S. A. (2013). The Effects of General and Specific Human Capital on longTerm Growth and Failure of Newly Founded Businesses. Entrepreneurship Theory and Practice, Vol. 37(4), pp. 923-941.

Van der Sluis, J. and Van Praag, M. (2008). Education and Entrepreneurship Selection and Performance: A Review of the Empirical Literature. Journal of Economic Surveys, Vol. 22(5), pp. 795-841.

Velez, C. M. (2009). The Probability of Transition to Entrepreneurship Revisited: Wealth, Education and Age. Annals of Finance, Vol. 5, pp. 421-441.

Wit, E., Heuvel, E., Romeyn, J. W. 2012. All models are wrong...': an introduction to model uncertainty. Statistica Neerlandica. Vol. 66(3), pp. 217-236. 